\title{
The Importance of Intertext in "Lolita"
}

\author{
Dr. Griselda Abazaj (Danglli) \\ "Aleksandër Moisiu" University, Durrës, Faculty of Education, Department of Foreign Languages \\ Email: griselda_abazaj@yahoo.com
}

\section{Doi:10.5901/jesr.2015.v5n3p217}

\begin{abstract}
This paper focuses on intertexts in Vladimir Nabokov's literary works, with a main emphasis on Edgar Allan Poe's allusions in "Lolita". Nabokov did not like to be referred to as a writer who was influenced by another one, let alone Edgar Allan Poe who had always been subject to debate due to his strange and difficult life and behavior. He used to be taken as an example when it comes to analyzing Sigmund Freud's study cases. American writers were not the ones Nabokov liked most but Edgar Allan Poe could not be part of that list because Nabokov indirectly showed his affection for him in many of his literary works. "Lolita", the masterpiece of Nabokov, wouldn't have been so famous unless we had had Poe's parody. A part of Lolita's name is inspired by Edgar Allan Poe's poem "Annabel Lee" and this poem is also alluded in the novel. You cannot understand "Lolita" unless you have read Poe's poem "Annabel Lee". The prevailing themes such as death love and beauty are present in both "Anabel Lee" and "Lolita". The intertexts in Nabokov's literary works help scholars have a deeper insight study into the principles of Nabokov's aesthetics.
\end{abstract}

Keywords: parody, aesthetics, intertext, love, death, beauty

\section{Introduction}

At the beginning of postmodernism, in the 60s, Nabokov's fame was great and, as a consequence, his literary works were an important part of the debate between modernism and postmodernism. Intertextuality, the pun on words and other features of postmodernism, are dominant in "Lolita". Literary works are generally influenced by previous well-known works of art, sometimes rewritten by another writer in a different way many years later, and a good reader is capable of discerning this influence. That's why whenever we read something, we frequently identify similarities with another work of art, and sometimes it even recalls a scene or character from another literary work. This does not imply that the later writer tries to copy another one but this is an indication of influence and love for that writer or his work.

The influence of a well-known writer upon another one is not a new phenomenon in literature. Nearly all writers have had their sources of inspiration and many of them have declared it openly and have attributed their fame to the influence of their favorite writer but this is not the case of Nabokov. A writer of genius is very rare as he is someone who creates something new, something that did not exist before. A good writer, regardless of the influence, leaves his own original traces and this is the reason why even when a work of art resembles another one, it has something unique in itself. It is the hand of the later writer. Again, this is not the case of Nabokov. Vladimir Nabokov stands between the two divisions: being a famous writer inspired by another one and being a genius because he gives clear indications of the influence and at the same time he is very special in the way he uses and hides the influences in his writings. That is what makes him a man of genius.

Nabokov did not like most of the contemporary American writers and he could distinguish just a few of them who deserved a place in the group of his most favourite writers such as Edgar Allan Poe, Henry James, John Updike, and J. D. Salinger. Edgar Allan Poe aesthetics played an important part in Vladimir Nabokov's writings from the beginning to the end of his literary career, both in poetry and prose. "Only recently have literary critics begun to explore the larger effect of Poe's prior texts on Nabokov's poetics, noting the pervasive thematic role of "enchanted hunters" of unpossessed shapes of loveliness and of "purloined letters", cloaked literary thefts, in the poems and narratives of both writers." (Aleksandrov, Peterson, 1995: 464)

\section{Intertext in "Lolita"}

The traces of the American writer Edgar Allan Poe can be easily found in the literary works of Vladimir Nabokov. The 
writer has used the tool of making something hidden obvious and the others will not find it. The key to "Lolita" is the intertext by Edgar Allan Poe. Just like the tool Poe uses in his story "The purloined letter", by making the letter obvious and they look for it in hidden places without noticing the letter lying on the table.

"At length my eyes, in going the circuit of the room, fell upon a trumpery filigree card-rack of pasteboard, that hung dangling by a dirty blue ribbon, from a little brass knob just beneath the middle of the mantelpiece. In this rack, which had three or four compartments, were five or six visiting cards and a solitary letter. This last was much soiled and crumpled. It was torn nearly in two, across the middle --as if a design, in the first instance, to tear it entirely up as worthless, had been altered, or stayed, in the second. It had a large black seal, bearing the D-- cipher very conspicuously, and was addressed, in a diminutive female hand, to D--, the minister, himself. It was thrust carelessly, and even, as it seemed, contemptuously, into one of the upper divisions of the rack.

No sooner had I glanced at this letter, than I concluded it to be that of which I was in search. To be sure, it was, to all appearance, radically different from the one of which the Prefect had read us so minute a description. Here the seal was large and black, with the D-- cipher; there it was small and red, with the ducal arms of the S-- family. Here, the address, to the Minister, was diminutive and feminine; there the superscription, to a certain royal personage, was markedly bold and decided; the size alone formed a point of correspondence. But, then, the radicalness of these differences, which was excessive; the dirt; the soiled and torn condition of the paper, so inconsistent with the true methodical habits of D--, and so suggestive of a design to delude the beholder into an idea of the worthlessness of the document; these things, together with the hyper obtrusive situation of this document, full in the view of every visitor, and thus exactly in accordance with the conclusions to which I had previously arrived; these things, I say, were strongly corroborative of suspicion, in one who came with the intention to suspect." (Levine, Bobbs, 1976:23)

For Poe and Nabokov the best way to hide something is making it obvious to the intruders. The intruders in Nabokov's case are his readers, who are at the same time his lovers and enemies, his co-players in a play of chess. One has to be defeated. Playing chess with Nabokov in literature requires a well-educated and clever reader, a reader who is familiar with the corpus of Nabokov's literary works because there are interlinks between Nabokov's works of literature and in order to understand one of them, you should have a clear idea of his whole literary works. "Only recently have literary critics begun to explore the larger effect of Poe's prior texts on Nabokov's poetics, noting the pervasive thematic role of "enchanted hunters", of unpossessed shapes of loveliness and of "purloined letters"..." (Aleksandrov, 1995:464)

"Lolita", Nabokov's masterpiece, wouldn't have been in our hands unless we had had the parody "coined" by Poe. The definition that Nabokov gives to parody is different from its general definition. For Nabokov, parody is not used to mock at a literary work, writer or literary model. On the contrary, parody for Nabokov is a tribute to his favourite writers. Nabokov's parodies on Poe are literary tributes, as Nabokov, just like Poe, believed that parody and poetry cannot live without each other. Poetry for Poe was "the rhythmical creation of beauty" (Poe, 1984: 75) and for both writers it is considered as mystic expression beyond reasoning.

"Lolita" as a controversial masterpiece is the core of Nabokov's admiration for Poe. "Edgar Allan Poe is the most conspicuous source of allusions in Humbert Humbert's highly literary confessional narrative of his romantic quest to possess the essence of "Lolita". (Appel, 1991: 328) Main themes found in Poe's literary works such as the death of a beautiful woman, the longing love for beauty, the use of doubles are all part of "Lolita" as well. Doubles in Nabokov's literary works does not refer only to the two sides of the coin of a character but to the way of narration, names of places etc. For example, Humbert, the narrator of "Lolita", refers to himself as Humbert Humbert or elsewhere he alludes to Edgar Allan Poe:

"In the slow clear hand of crime I wrote: Dr. Edgar H. Humbert and daughter, 342 Lawn Street, Ramsdale. A key (342!) was half-shown to me (magician showing object he is about to palm)--and handed over to Uncle Tom. Lo, leaving the dog as she would leave me some day, rose from her haunches; a raindrop fell on Charlotte's grave; a handsome young Negress slipped open the elevator door, and the doomed child went in followed by her throat-clearing father and crayfish Tom with the bags. Parody of a hotel corridor. Parody of silence and death." (Nabokov, 2000: 118)

\subsection{The underlying meaning of the title}

In order to better understand the intertext of Poe in "Lolita" we should focus on the title, where in Lolita's name we find a syllable which is part of the name Annabel Lee, the poem with the same title by Edgar Allan Poe. This feature recalls Umberto Echo's idea that the title of a postmodernist novel should create many relations with other literary works and this is the case of "Lolita". This novel establishes relations with the literary works of Edgar Allan Poe, Prosper Mérimée, etc. Like many other postmodernist literary works, "Lolita" is not what it claims to be. This literary work has the unexplainable 
power to ruin the reader's expectations. It makes the reader correct, time and again, the way he tries to read the novel in order to understand it, because the most important thing is always hidden in a text which at a first sight looks just like a descriptive passage. The reader plays an important role in the reading of Nabokov's literary works.

Fraysse (Fraysse, vol.12) - argues that careful readers of "Lolita" can notice the allusion about Edgar Allan Poe and understand that the three syllables in the name Lolita have to do with three other nymphets that are the precursors of Lolita. The first syllable Lo has to do with Loo, a character of Herman Melville, who is a teenager girl living in an enchanted island and a mature man falls in love with her. "Her "hazel" eyes possibly gave Lolita the family name that is used in Humbert's manuscript (all the more so as "Haze" only rhymes with her real name) while the name of her father translated into English (Jeremiah in-the-dark), possibly gave her the name she had in Nabokov's manuscript (Juanita Dark). The Polynesian for Jeremiah-in-the-dark is Ereemar Po-po, which nicely introduces the second intertextual allusion to Humbert Humbert's favorite poet-poet and his Annabel Lee hiding in the second syllable of Lolita's name. Finally the last syllable of Lolita's name rhymes with Mérimée's Carmencita to whom there are quite a few allusions in the novel." (Fraysse, vol.12)

When Humbert, the character, and at the same time narrator of the novel, starts his narration, he makes it clear: "In point of fact there might have been no Lolita at all, had I not loved, one summer, a certain initial girl-child. In a princedom by the sea" (Nabokov, 2000: 9). A careful reader immediately recalla the famous poem of Edgar Allan Poe:

\author{
"It was many and many a year ago, \\ In a kingdom by the sea, \\ That a maiden there lived whom you may know \\ By the name of Annabel Lee; \\ And this maiden she lived with no other thought \\ Than to love and be loved by me. \\ She was a child and I was a child, \\ In the kingdom by the sea, \\ But we loved with a love that was more than love- \\ I and my Annabel Lee- \\ With a love that the wingéd seraphs of Heaven \\ Coveted her and me" (Poe, 1984: 102)
}

The allusion is so clear because even the first lover of Humbert when he was a little boy was called "Annabel Leigh". Even his life since the beginning of the novel seems similar to that of Edgar Allan Poe, whose mother died when he was very young and later he married his cousin Virginia, younger than him. It is important to highlight the fact that first Nabokov intended to entitle "Lolita" "A kingdom by the sea" which recalls Poe's poem "Annabel Lee".

\title{
3. The Aesthetics Crossing Lines of Nabokov and Poe
}

"Nabokov's numerous parodies of Poe are literary tributaries that flow from a common source of inspiration- the insight that genuine poetry is inseparable from the spirit of parody." (Aleksandrov, 1995: 465) Certainly, Nabokov parodies Poe in this novel and we know that the meaning of parody is "a literary or artistic work that uses imitation, as of the characteristic style of an author or work, for comic effect or ridicule." (www.freedictionary.com, online) Before judging that Nabokov parodies Poe in "Lolita", we should have prior knowledge about Nabokov's own definition of parody. For Nabokov, parody was a highly praised literary work that demonstrated his admiration for another writer and in our case we can definitely argue that Nabokov parodies Poe because he was one of the few writers Nabokov admired.

When it comes to Poe and Nabokov's principles in relation to literature they have many things in common. They both had a passion for beauty and wrote everything for its sake. Nabokov and Poe were of the same opinion that a poem should give shape to beauty which is subjective and its duty was not to convey a moral. A real poem is not a poem of ideas.

Nabokov hated the fact that biographers poke their noses into writers' life and he believed that knowing the life of a writer is not a prerequisite to understand his literary works. Poe's critics and biographers had analyzed Poe according to Freudian psychoanalysis and they thought that they could give an answer to every enigma about Poe's works based on his scandalous and unhappy life. By using Poe as an example, Nabokov made it difficult for his critics and biographers to know facts about his life. He had disputes with Andrew Field, his biographer, when Nabokov was alive, because he tried hard to discover the past of Vladimir Nabokov, but the writer sued him and even mocked him in his novel "Look at the Harlequins!" Poe is alluded even in "Pale Fire", in Shade's poetry and in "Transparent things". 


\section{Conclusions}

The influence of Edgar Allan Poe is clear throughout Nabokov's masterpiece "Lolita" On the other hand, Poe's literary writings and life are strongly related to Sigmund Freud's psychoanalysis. Sigmund Freud, who is considered one of the most influencing geniuses in psychoanalysis, the one who made a revolution in the twentieth century thinking, can be traced throughout Nabokov's literary works and foremost in "Lolita". Freud had invaded the literary thought of that time and Nabokov could not neglect him as well, but being powerless to exclude him from his works, Nabokov choses a wise way by making fun of Freud's principles. Nabokov strongly believed that a good writer is foremost a psychological writer.

The narration of Humbert in "Lolita" is constructed according to the Freudian theory of the nature and origins of perversities. In this novel we find the typical sexual trauma between Humbert and Anabel Leigh, the so-called coitus rudely interruptus. This can be understood as an unfulfilled desire for a love relationship which ended without a sexual relationship. Humbert tells us about his story with Anabel Leigh when they were children and he assures us that "in point of fact, there might have been no Lolita at all had I not loved, one summer, a certain initial girl-child. In the princedom by the sea." (Nabokov, 2000: 9). We can add other facts to coitus rudely interruptus such as Humbert's claim that he is sexually impotent and the tragical loss of Humbert's mother when he was only three years old. Lolita for Humbert is just a copy of his beloved Anabel Leigh.

Nabokov did not like to be part of the crowds and he adored those things that were special. This is the main reason why he hated crowds, groups or literary currents, because they made generalizations and excluded the individual experience, which for Nabokov is the real truth that matters. Nabokov was always criticized for repetition in his literary works and for a strange relation that his literary works have with each other, and in an interview (Interview with Herbert Gold, 1977: 107) he would state that there are great writers who imitate many other writers of the past and the present, but the artistic originality copies only itself. The artistic originality copies only itself despite Nabokov's objection that other writers may have inspired him in writing, we believe that he can be studied in comparison with the writers he liked best and even with those he hated just because he considered them rivals in literature. These studies may help Nabokovian scholars have a better understanding of Nabokov's literary aesthetics.

\section{References}

Alexandrov Vladimir E., (1995), The Garland Companion to Vladimir Nabokov, Garland Publishing, INC. New York \& London. Appel, Alfred Jr., (1991), The Annotated Lolita, New York: Vintage books.

Fraysse Susanne, Worlds Under Erasure: Lolita and Postmodernism, Cycnos|Volume $12 n^{\circ} 2$ Nabokov : At the Crossroads of Modernism and Postmodernism, France.

Interview with Herbert Gold, (1977) The Paris Review Interviews: Writers at Work, $4^{\text {th }}$ series.

Nabokov, Vladimir, (2000).Lolita. London: Penguin Books

Poe, Edgar Allan, (1984) Annabel Lee - Poetry and Tales, New York: Literary Classics of the United States.

Poe, Edgar Allan, (1984), Essays and Reviews, New York: Viking Press.

Poe, Edgar Allan, Levine Stuart, Bobbs-Merrill, (1976) The short fiction of Edgar Allan Poe. www.freedictionaries.com, online 